\title{
ANTIBODY RESPONSES ELICITED IN MICE IMMUNIZED WITH BACILLUS SUBTILIS VACCINE STRAINS EXPRESSING STX2B SUBUNIT OF ENTEROHAEMORRAGIC ESCHERICHIA COLI O157:H7
}

\author{
Gomes, P.A.D.P. ${ }^{1}$; L.V. Bentancor ${ }^{2}$; J.D. Paccez ${ }^{1}$; M.E. Sbrogio-Almeida ${ }^{3}$ M. S. Palermo² ${ }^{\text {; R.C.C. Ferreira }}{ }^{\text {; }}$ \\ L.C.S. Ferreira ${ }^{1 *}$ \\ ${ }^{1}$ Universidade de São Paulo, Departamento de Microbiologia, São Paulo, SP, Brasil; ${ }^{2}$ Academina Nacional de Medicina, \\ Instituto de Investigaciones Hematológicas, Buenos Aires, Argentina; ${ }^{3}$ Instituto Butantan, Divisão de Produção e \\ Desenvolvimento Tecnológico, São Paulo, SP, Brasil.
}

Submitted: April 16, 2008; Returned to authors for corrections: August 07, 2008; Approved: March 03, 2009.

\begin{abstract}
No effective vaccine or immunotherapy is presently available for patients with the hemolytic uremic syndrome (HUS) induced by Shiga-like toxin (Stx) produced by enterohaemorragic Escherichia coli (EHEC) strains, such as those belonging to the O157:H7 serotype. In this work we evaluated the performance of Bacillus subtilis strains, a harmless spore former gram-positive bacterium species, as a vaccine vehicle for the expression of Stx2B subunit (Stx2B). A recombinant B. subtilis vaccine strain expressing Stx2B under the control of a stress inducible promoter was delivered to BALB/c mice via oral, nasal or subcutaneous routes using both vegetative cells and spores. Mice immunized with vegetative cells by the oral route developed low but specific anti-Stx2B serum IgG and fecal IgA responses while mice immunized with recombinant spores developed anti-Stx2B responses only after administration via the parenteral route. Nonetheless, serum anti-Stx2B antibodies raised in mice immunized with the recombinant $B$. subtilis strain did not inhibit the toxic effects of the native toxin, both under in vitro and in vivo conditions, suggesting that either the quantity or the quality of the induced immune response did not support an effective neutralization of Stx2 produced by EHEC strains.
\end{abstract}

Key words: EHEC, Stx, Bacillus subtilis, vaccines, HUS.

\section{INTRODUCTION}

Shiga-like toxin (Stx)-producing enterohaemorragic Escherichia coli (EHEC) strains have been recognized as emerging food-borne pathogens that cause bloody diarrhea, hemorrhagic colitis and, in some cases, hemolytic uremic syndrome (HUS), with high mortality rates mainly among children and elderly people $(13,18)$. There is neither a vaccine nor an effective treatment to avoid EHEC infection or HUS control (9) but, given the importance of Stx in the EHECassociated diseases, several attempts to use Stx toxoids or the Stx B subunit (Stx2B) have been reported $(1,3,11,12$, 20,22).
Bacillus subtilis strains have been engineered to express different antigens as live recombinant vaccine vehicles delivered via the oral route either as spores or vegetative cells $(5,6,8,16$, 17,21). Previous attempts to express the B subunit of heat labile toxin (LTB), produced by enterotoxigenic $E$. coli (ETEC) strains, have demonstrated that orally delivered $B$. subtilis vaccine strains may elicit protective systemic antibody responses to a lethal toxin challenge in mice (17). These results suggest that EHEC vaccines based on Stx2B-expressing B. subtilis strains may be feasible. Therefore, the aim of the present study was to evaluate the immunogenicity and potential protective effects of Stx2B-producing B. subtilis strains as a vaccine strategy against EHEC infection.

*Corresponding Author. Mailing address: Department of Microbiology, Biomedical Sciences Institute, University of São Paulo, Av. Prof. Lineu Prestes, 1374, Cidade Universitária, SP, Brasil. 05508-000. Phone: + 5511-30917408. Fax: + 5511 30917354. E-mail: lcsf@usp.br 


\section{MATERIALS AND METHODS}

Bacterial strains and growth conditions. The bacterial strains used in the present study are described in Table 1. All bacterial strains were routinely cultivated in Luria-broth (LB) with added neomycin $(25 \mu \mathrm{g} / \mathrm{mL})$ and chloramphenicol $(10 \mu \mathrm{g} /$ $\mathrm{mL})$, for B. subtilis, or ampicilin $(100 \mu \mathrm{g} / \mathrm{mL})$, for E. coli. Sporulation of B. subtilis strain was induced in Difcosporulation media (DSM) using the previously described exhaustion method (14). Chemical competent $E$. coli cells were prepared with $\mathrm{CaCl}_{2}$ treatment, according to a standard protocol (19), while spontaneously induced $B$. subtilis competent cells were obtained according to the two-step transformation method (4).

\section{Plasmid construction}

The entire stx 2 coding sequence (without the signal peptide coding sequence) was amplified by PCR using total DNA extracted from E. coli $\mathrm{O} 157: \mathrm{H} 7 \mathrm{EDL} 933$ strain, as template, and primers F1 (5' TCTGTTAATAGATCTATGGCGGATTGTG - 3') and R1 (5' CGAATCAGACGTCGCCTCAGTCATTATT - 3') containing the BglII and AatII restriction sites (underlined sequences), respectively. The resulting 229 bp fragment was cloned into the shuttle pHCMC03 vector (15) previously cleaved with BamHI and AatII restriction enzymes. The recombinant plasmid construction was confirmed by restriction analysis and automated DNA sequencing and named pLDVP1. It expresses the Stx2B subunit, accumulated as an intracellular protein, under the control of the stress inducible sigma B-dependent promoter derived from the $B$. subtilis $g s i B$ gene (15). The pLDVP1 plasmids were replicated in competent $E$. coli DH5a cells and, then, transferred to B. subtilis WW02.

\section{Detection of Stx2B by SDS-PAGE and immunoblots}

SDS-PAGE and immunoblots of recombinant $B$. subtilis strains, as well as purified Stx2B, were carried out by previously reported procedures $(16,17)$. Detection of Stx2B in immunoblots was carried out with a mouse anti-Stx2B serum generated in the laboratory with recombinant affinity purified Stx2B produced in E. coli and an anti-mouse IgG peroxidase conjugate (Sigma).

\section{Preparation of $B$. subtilis spores}

Sporulation of B. subtilis was carried out with the exhaustion method, as previously described (14). Cultures were harvested $48 \mathrm{~h}$ after sporulation onset, followed by temperature and lysozyme treatment to inactivate any residual vegetative cells (16). Viable spores were titered for viable particles and, then, stored at $-20^{\circ} \mathrm{C}$ until use.

\section{Immunizations regimens}

Female BALB/c mice were supplied by the isogenic mouse breeding facility of the Department of Parasitology, Biomedical Sciences Institute (ICB), University of São Paulo. All animal handling was in accordance to the rules defined by the Institute of Biomedical Sciences ethics committee for use of laboratory animals. Groups of at least five 10 weeks old mice were inoculated via the oral (p.o), nasal (i.n) or subcutaneous (s.c.) routes with vegetative cells or spores of the $B$. subtilis strains. For the p.o. administrations, aliquots $(0.5 \mathrm{ml})$ containing vegetative cells $\left(10^{10} \mathrm{CFU}\right)$ or spores $\left(10^{9} \mathrm{CFU}\right)$ were delivered with a stainlesssteel round tip gavage cannule in three consecutive daily doses at days 1, 2, 3, 14, 15, 16, 28, 29, 30 and 42, 43, 44. Mice received $(0.5 \mathrm{ml}) 0.1 \mathrm{M}$ sodium bicarbonate solution $30 \mathrm{~min}$ before administration of bacteria and spores. The i.n. and s.c administrations were performed with $20 \mu \mathrm{l}$ (containing $10^{8} \mathrm{CFU}$ ) and $200 \mu \mathrm{L}$ (containing $10^{\circ} \mathrm{CFU}$ ), respectively, at days $1,14,28$ and 42 . B. subtilis cultures were incubated for $2 \mathrm{~h}$ at $45^{\circ} \mathrm{C}$ during exponential growth in order to activate Stx $2 \mathrm{~B}$ expression under the control of the $g s i B$ promoter (16). Blood and fecal samples were collected one day before each immunization, corresponding to $0,13,27$ and 41 and ten days after the last immunization (day 55). Individual blood samples were collected, pooled and, then, stored at $-20^{\circ} \mathrm{C}$ for further testing. Fecal material was first freezedried and stored at $-20^{\circ} \mathrm{C}$ further testing.

\section{ELISA}

Anti-Stx2B antibody responses were measured in 96-well Maxisorp (Nunc) microtiter plates coated overnight at $4^{\circ} \mathrm{C}$ with recombinant Stx2B protein at a concentration of $1 \mu \mathrm{g} / \mathrm{ml}$ in phosphate buffered saline (PBS). The ELISA procedure was accomplished according to previously published methods $(3,16)$.

Table 1. Bacterial strains used in the present study.

\begin{tabular}{|c|c|}
\hline Bacterial strain & Main characteristics \\
\hline B.subtilis WW02 & leuA8 metB5 trpC2hsrdRM1 amyE::neo \\
\hline B. subtilis LDV4 & WW02 carrying pHCMC03 \\
\hline B. subtilis LDVP1 & WW02 carrying pLDV4 (Stx2B under control PgsiB) \\
\hline E. coli $\mathrm{DH} 5 \alpha$ & $\begin{array}{l}\text { recAl endA1 gyrA96 glnV44=supE44 relAl deo } R \Delta(\text { lacZargF }) U 169 \text { hsdR17 thi-1 } \lambda \text { j80dlac } \\
\Delta\left(\text { lacZ) } \mathrm{m} 15 \mathrm{~F}^{-}\right.\end{array}$ \\
\hline
\end{tabular}




\section{In vitro and in vivo Stx 2 neutralization test}

Stx 2 whole cell extracts were prepared with the $E$. coli JM109 strain transformed with a plasmid carrying the native $s t x 2$ operon cloned into the EcoRI site of pGEMT-EASY. In vitro anti-Stx neutralization activity of sera harvested from mice immunized with the $B$. subtilis vaccine strain was determined following incubation of recombinant Stx2 with serial dilutions of each tested serum sample for $1 \mathrm{~h}$ at $37^{\circ} \mathrm{C}$ followed by $1 \mathrm{~h}$ at $4^{\circ} \mathrm{C}$. The mixtures were transferred to microplates seeded with Vero cells and incubated for $48 \mathrm{~h}$ at $37^{\circ} \mathrm{C}$. The Stx cytotoxic effects were determined after crystal violet staining of live cells, according to the previously described procedure (3). A control Stx2 serum, raised in rabbit inoculated with the native Stx2 toxin, was kindly provided by Dr. Roxane M. F. Piazza, from Butantan Institute (São Paulo, Brazil). In vivo Stx2 neutralization tests were carried out after intravenous injection of native Stx $2\left(3 \times \mathrm{LD}_{100}\right)$ into the retro-orbital plexus of BALB/c mice after incubation with antiStx2B sera harvested from mice submitted to different immunization regimens with the $B$. subtilis LDVP1 and LDV4 vaccine strains, using the same conditions cited above. Stx2 lethal challenges $\left(3 \times L_{100}\right)$ were performed with $\mathrm{BALB} / \mathrm{c}$ immunized with vegetative cells or spores of the B. subtilis vaccine strains delivered via p.o. or s.c. routes under the immunization regimens described above.

\section{RESULTS}

The Stx2B coding sequence, without the signal peptide encoding sequence, was amplified from the genomic DNA of an EHEC 0157:H7 strain and cloned into the B. subtilis pHMC03 expression vector. The amount of Stx2B produced by the recombinant $B$. subtilis LDVP1 strain was monitored in western blots developed with an anti-Stx2B serum raised in mice immunized with a recombinant Stx2B produced in $E$. coli. The amount of Stx2B produced by vegetative cells or spores of the LDVP1 strain was bellow the detection limit of the assay, which corresponded to $125 \mathrm{ng}$ of antigen in $10^{6}$ vegetative cells.

The immunogenicity of the $B$. subtilis LDVP1 strain was evaluated in $\mathrm{BALB} / \mathrm{c}$ mice after administration of vegetative cells or spores via two mucosal (p.o. and i.n.) and one parenteral (s.c.) inoculation routes (Fig. 1). As shown in Fig. 1A, kinetics of the anti-Stx2B serum IgG responses elicited in mice immunized with the $B$. subtilis LDVP1 strain ranged from undetectable levels to reverse titers of approximately 120 . Higher anti-Stx $2 B$ titer in mice immunized with LDVP1 vegetative cells were recorded in mouse groups immunized with four doses via the p.o. route, while higher anti-Stx2B serum IgG titers were recorded in mice immunized with two spore doses delivered via the s.c. route (titer of approximately 170), as shown in Fig. 1B, or via the i.n. route (titer of approximately 90), as shown in Fig. 1C. Secreted fecal anti-Stx2B IgA responses were detected only in mice orally immunized with three (titer of approximately 250) or four (titer of approximately 100) doses of vegetative cells of the B. subtilis LDVP1 strain, as shown in Fig. 1D. These results indicate that, in spite of the low (vegetative cells) or null (spores) antigen loads, the B. subtilis LDVP1 strain elicited specific anti-Stx2B antibody responses in $\mathrm{BALB} / \mathrm{c}$ mice immunized via different immunization routes.

Pathogen-neutralizing Stx2B-specific antibody responses must provide complete protection to Stx 2 cellular damages. In order to evaluate the anti-Stx neutralization activity of serum antibodies raised in mice immunized with the $B$. subtilis LDVP1 vaccine strain, we tested serum pools with anti-StxB antibodies in toxin neutralization tests carried out in vitro with cultured Vero cells and in vivo with BALB/c mice challenged with native Stx2 previously incubated with serum pools harvested from mice immunized with recombinant $B$. subtilis cells or spores (Table 2). Serum harvested from mice immunized with $B$. subtilis LDVP1 vegetative cells or spores did not show Stx2 neutralization activity following incubation with the native holotoxin. As a positive control, we tested an anti-Stx2 serum

Table 2. In vitro and in vivo anti-Stx2 neutralization activity of serum antibodies raised in mice immunized with the recombinant B. subtilis vaccine strains.

\begin{tabular}{ccccc}
\hline Serum $^{\mathrm{a}}$ & $\begin{array}{c}\text { IgG } \\
\text { titers }^{\mathrm{b}}\end{array}$ & $\begin{array}{c}\text { Dilution } \\
\text { of serum }^{\text {activity }}\end{array}$ & $\begin{array}{c}\text { In vitro } \\
\text { Neutralizing }\end{array}$ & $\begin{array}{c}\text { In vivo } \\
\text { Neutralizing } \\
\text { activity }^{\mathrm{d}}\end{array}$ \\
\hline LDV4 cells & 0 & $1: 5$ & - & $0 / 3$ \\
LDVP1 cells & 117 & $1: 5$ & - & $0 / 3$ \\
LDVP1 spores & 166 & $1: 5$ & - & $\mathrm{ND}^{\mathrm{e}}$ \\
Stx2 & 40,136 & $1: 100$ & $\mathrm{ND}$ & $3 / 3$ \\
& & $1: 300$ & + & $\mathrm{ND}$ \\
& & $1: 1,000$ & + & $3 / 3$ \\
& & $1: 10,000$ & $\mathrm{ND}$ & $0 / 3$ \\
\hline
\end{tabular}

${ }^{a}$ Tested serum samples: LDV4 cells and LDVP1 cells, serum pools harvested from mice p.o. immunized with four doses $\left(10^{10}\right.$ vegetative cells/each dose) of B. subtilis LDV4 and LDVP1 strains, respectively; LDVP1 spores, sera harvested from mice s.c. immunized with two doses ( $10^{9}$ spores/each dose) of the B. subtilis LDVP1 strain; Stx2, anti-Stx2 serum raised in rabbits following parenteral inoculation of enriched Stx2 toxoids preparations;

b Serum anti-Stx2B IgG titers represented as values recorded with serum pools harvested from mice submitted to different immunization regimens;

${ }^{\mathrm{c}}$ In vitro anti-Stx 2 neutralization effects measured in Vero cells incubated in the presence of native Stx2 toxin previously incubated with the tested sera. -, no anti-Stx2 neutralizing activity; +, 100\% anti-Stx2 neutralization activity; ND, not done;

${ }^{\mathrm{d}}$ Survival of BALB/c mice challenged with a lethal load of native Stx2 toxin. Values expressed as number of survivors/total number of inoculated mice;

${ }^{\mathrm{e}} \mathrm{ND}$, not done. 
(A)

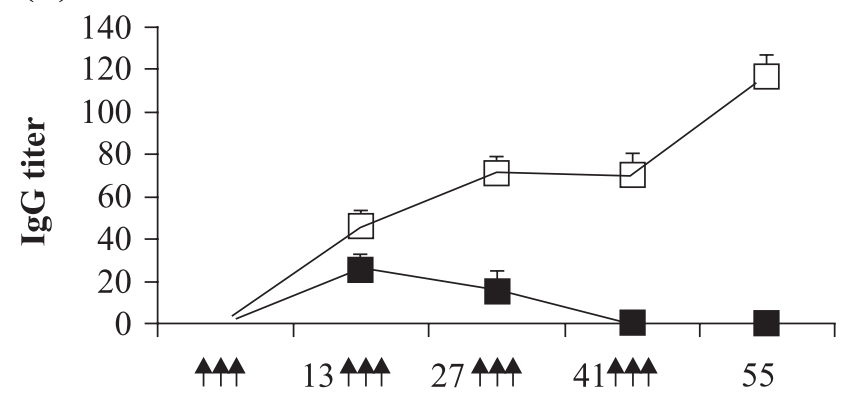

Days post primary imunization

(C)

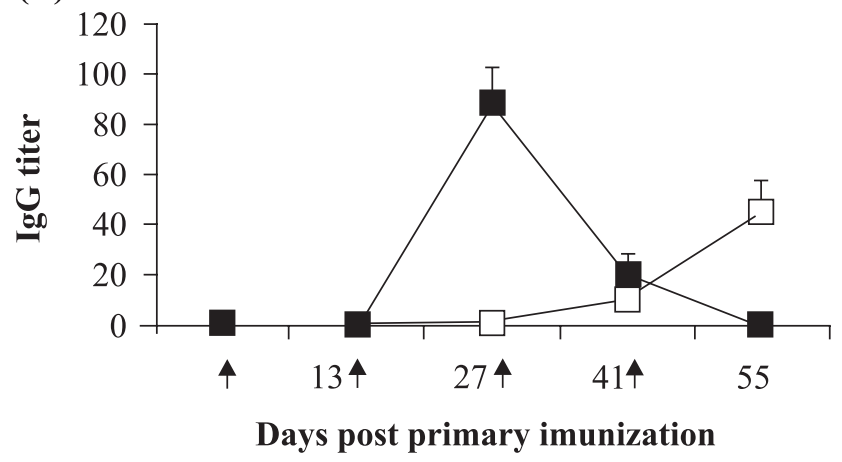

(B)

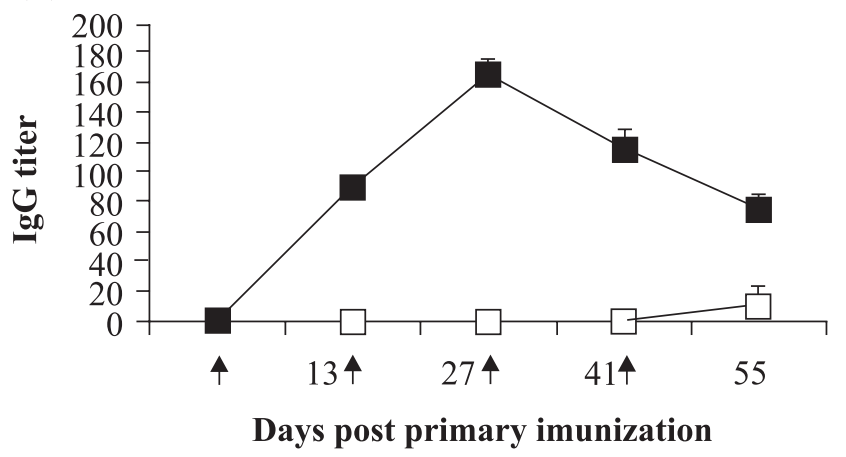

(D)

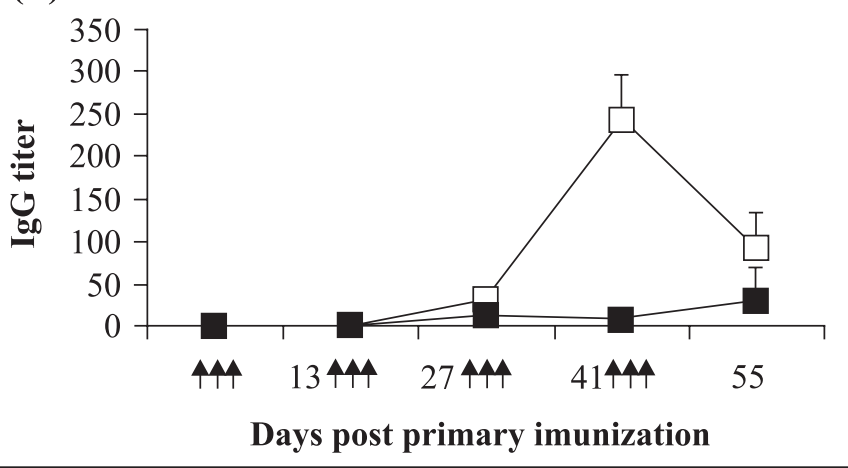

Figure 1. Induction of anti-Stx2B serum (IgG) and fecal (IgA) responses elicited in BALB/c mice immunized via differents routes with the recombinant $B$. subtilis LDVP1 vaccine strain. Anti-Stx2B systemic (serum) $\operatorname{IgG}(\mathrm{A}, \mathrm{B}, \mathrm{C})$ and secreted (fecal) $\operatorname{Ig} A$ (D) responses were measured in female BALB/c mice immunized via p.o. (A), s.c.(B) or i.n. (C) administration routes. Anti-Stx2B fecal IgA responses were detected only in mice immunized via the p.o. administration route (D). Mice were immunized with vegetative cells $(\square)$ or spores $(\square)$ of the B. subtilis LDVP1 strain. All values were deducted with those measured in negative control mice immunized with the $B$. subtilis LDV4 strain. Arrows indicate the days in which the vaccine doses were administered. Values represented anti-Stx2B titers measured in serum pools of four animals per immunization group and represented by means \pm SE.

raised in rabbit immunized with the Stx2. Similar results were also observed under in vivo conditions.

As a final evaluation of the Stx neutralization activity of serum antibodies raised in mice immunized with the $B$. subtilis LDVP1 strain, mice vaccinated with vegetative cells (p.o.) or spores (s.c.) were challenged with a lethal Stx 2 load. Mice were i.v. challenged with Stx at time points corresponding to the highest anti-Stx2B titers determined in IgG-ELISA, but none of them survived longer than control mice immunized with the $B$. subtilis LDV4 strain (data not shown).

\section{DISCUSSION}

The present report describes for the first time the use of a genetically modified B. subtilis strain as a live vehicle for the expression of Stx2 B subunit as potential a vaccine approach against EHEC O157:H7, and other Stx2-producing EHEC strains. Our results clearly show that, despite the low immunogenicity of the target antigen, mice immunized with either $B$. subtilis vegetative cells or spores, develop specific systemic (serum $\mathrm{IgG}$ ) and secreted (fecal IgA) anti-Stx2B responses.

Nonetheless, serum anti-Stx2B antibodies raised in mice immunized with the recombinant $B$. subtilis strain did not inhibit the toxic effects of the native toxin, both under in vitro and in vivo conditions, suggesting that the recombinant protein expressed by the vaccine vector lost important epitopes required for the generation of antibodies able to effective neutralize Stx 2 produced by EHEC strains and/or that the generated antibodies did not achieve a minimum concentration required for effective binding and neutralization of the native toxin.

In vitro expression of Stx2B by recombinant $B$. subtilis vegetative cells was under the detection limit of the tested 
Vaccine for E. coli $\mathrm{O} 157: \mathrm{H} 7$

experimental conditions. This finding may be reasoned by the reduced in vitro expression of Stx2B by recombinant $B$. subtilis cells and the relatively low sensitivity of the detection method. Under our experimental conditions Stx2B is expressed by vegetative cells in amounts lower than previously detected with the ETEC LTB $(16,17)$. The anti-Stx2B sera employed to monitor the antigen in bacterial extracts detected a minimum of $120 \mathrm{ng}$ of Stx2B toxin, while other sera, such as those previously used to quantify LTB, had a higher sensitivity $(16,17)$. Additionally, the low immunogenicity of Stx2B, under different vaccine formulations, has been previously reported $(1,2,3,11,12)$. Thus, it is possible that either the low amount of Stx2B produced by the B.subtilis vaccine strains and/or the reduced immunogenicity of the protein contributed to the low antibody levels detected in serum and fecal samples collected from vaccinated mice. Further improvements of the $B$. subtilis vaccine strains might consider expression of the StxB-encoding gene under control of stronger constitutive promoters and expression of the recombinant peptide attached to the cell wall or secreted to the extracellular medium (17). In addition, recent findings demonstrated that recombinant $B$. subtilis efficiently boost secreted and systemic specific antibody responses in mice previously primed with DNA vaccines encoding the same antigen (10), an alternative currently under investigation to improve the protective potential of this vaccine strategy.

Stx2B-specific serum antibody responses elicited in mice immunized with cells or spores of the LDVP1 strain did not confer protective immunity to Stx2. The lack of Stx 2 neutralizing activity in serum samples of mice immunized with the $B$. subtilis vaccine strains may be explained either by the low anti-Stx2B titers or altered specificity of the induced antibody responses. Since the recombinant protein expressed by vegetative cells or germinating spores accumulated into the cytoplasm of the vaccine strain, the Stx2B monomers are not expected to assume the conformation required to holotoxin assemblage, thus, restricting the repertoire of epitopes recognized by the induced antibodies. Similar findings have been reported for antibodies raised in mice immunized with $B$. subtilis expressing the protective antigen of B. anthracis (7). Therefore, improvement of anti-Stx $2 \mathrm{~B}$ antibody epitope specificity in mice immunized with $B$. subtilis vaccine strains may consider the expression of a secreted form of the antigen or fusion of Stx2B with a carrier protein allowing secretion and correct conformation of the encoded peptide.

\section{ACKNOWLEDGMENTS}

This work was supported by grants from Fundação de Amparo à Pesquisa do Estado de São Paulo (FAPESP), Conselho Nacional de Desenvolvimento Científico e Tecnológico (CNPq) and Coordenação de Aperfeiçoamento de Pessoal de Nível Superior (CAPES). We thankfully acknowledge the skillful technical suport of Camila Calderon.

\section{RESUMO \\ Resposta de anticorpos obtidas em camundongos imunizados com linhagens vacinais de Bacillus subtilis expressando a subunidade B da Stx2 de Escherichia coli 0157:H7 enterohemorrágica}

Até o presente o momento, não há vacina ou imunoterapia disponível para pacientes com Síndrome Hemolítica Urêmica (SHU) induzida pela toxina Shiga-like (Stx) produzida por linhagens de Escherichia coli entero-hemorragica (EHEC), tais como as pertencentes ao sorotipo O157:H7. Neste trabalho, avaliamos a performance de Bacillus subtilis, uma espécie bacteriana gram-positiva não-patogênica formadora de esporos, como veículo vacinal para a expressão da subunidade B da Stx2B (Stx2B). Uma linhagem vacinal recombinante de B. subtilis expressando Stx2B, sob o controle de um promoter induzível por estresse, foi administrada a camundongos $B A L B / c$ por via oral, nasal ou subcutânea usando células vegetativas e esporos. Camundongos imunizados com células vegetativas e esporos pela via oral desenvolveram títulos anti-Stx2B baixos, mas específicos, de IgG sérico e IgA fecal, enquanto camundongos imunizados com esporos recombinates desenvolveram resposta anti-Stx2B apenas após a administração pela via parenteral. No entanto, anticorpos produzidos em camundongos imunizados com a linhagem recombinante de $B$. subtilis não inibiram os efeitos tóxicos da toxina nativa em condições in vitro e in vivo, sugerindo que a quantidade e/ou a qualidade da resposta imune gerada não suportam uma neutralização efetiva da Stx2 produzidas por linhagens de EHEC.

\section{Palavras-chave: EHEC, Stx, Bacillus subtilis, vacinas, SHU}

\section{REFERENCES}

1. Bielaszewska, M.; Clarke, I.; Karmali, M.A.; Petric, M. (1997). Localization of intravenously administered verocytotoxins (Shigalike toxins) 1 and 2 in rabbits immunized with homologous and heterologous toxoids and toxin subunits. Infect. Immun. 65, 2509 2516.

2. Byun, Y.; Omura, M.; Fujihashi, K.; Yamamoto, S.; McGhee, J.R.; Udaka, S.; Kiyono, H.; Takeda, Y.; Kohsaka, T.; Yuki, Y. (2001) Nasal immunization with $E$. coli verotoxin 1 (VT1)-B subunit and a nontoxic mutant of cholera toxin elicits serum neutralizing antibodies. Vaccine 19, 2061-2070.

3. Capozzo, A.V.E.; Creydt, V.P.; Dran, G.; Fernández, G.; Gómez, S.; Bentancor, L.V.; Rubel, C.; Ibarra, C.; Isturiz, M.; Palermo, M.S. (2003). Development of DNA Vaccines against HemolyticUremicSyndrome in a Murine Model. Infect Immun. 71, 39713978.

4. Cutting, S.M.; Vander-Horn, P.B. (1990) Genetic Analysi. In: Harwood, C.R.; Cutting, S.M. (eds). Molecular biological methods for Bacillus. Chichester, UK, Wiley, p. 391-450.

5. Duc, L.H.; Hong, H.A.; Fairweather, N.; Ricca, E.; Cutting, S.M. (2003). Bacterial spores as vaccine vehicles. Infect. Immun. 71 2810-2818 
6. Duc, L.H.; Hong, H.A.; Cutting, S.M. (2003). Germination of the spore in the gastrointestinal tract provides a novel route for heterologous antigen delivery. Vaccine 21, 4215-4224.

7. Duc, L.H.; Hong, H.A.; Atkins, H.S.; Flick-Smith, H.C.; Durrami, Z.; Rijpkema, S.; Titball, R.W.; Cutting, S.M. (2007). Immunization against anthrax using Bacillus subtilis spores expressing the anthrax protective antigen. Vaccine 25, 346-355.

8. Ferreira, L.C.S.; Ferreira, R.C.C.; Schumann, W. (2005). Bacillus subtilis as a tool for vaccine development: from antigen factories to delivery vectors. An. Acad. Bras. Cien. 77, 113-124.

9. Karmali, M.A. (2004). Prospects for preventing serious systemic toxemic complications of Shiga toxin-producing Escehrichia coli infections using Shiga toxin receptor analogues. J. Infect. Dis. 189, 355-359.

10. Luiz, W.B.; Cavalcante, R.C.M.; Paccez, J.D.; Souza, R.D.; SbrogioAlmeida, M.E.; Ferreira, R.C.C.; Ferreira, L.C.S. (2008). Boosting systemic and secreted antibody responses in mice orally immunized with recombinant Bacillus subtilis strains following parenteral priming with a DNA vaccine encoding the enterotoxigenic Escherichia coli (ETEC) CFA/I fimbriae B subunit. Vaccine 26, 3998-4005.

11. Marcato, P.; Mulvey, G.; Read, R.J.; Helm, K.V.; Nation, P.N.; Armstrong, G.D. (2001). Immunoprophilactic potential of cloned Shiga toxin 2 B subunit. J. Infect. Dis. 183, 435-443.

12. Marcato, P.; Griener, T.P.; Mulvey, G.L.; Armstrong, G.D. (2005). Recombinant Shiga toxin B subunit-keyhole limpet hemocyanin conjugate vaccine protects mice from shigatoxemia. Infect Immun. $73,6523-6529$

13. Nataro, J.P.; Kaper, J.B. (1998). Diarrheagenic Escherichia coli. Clin. Microbiol. Rev. 11, 142-201.

14. Nicholson, W.L.; Setlow, P. (1990). Sporulation germination and outgrowth. In: Harwood, C.R.; Cutting, S.M. (eds). Molecular biological methods for Bacillus. Chichester, UK: Wiley, p. 391-450.
15. Nguyen, H.D. ; Nguyen, Q.A. ; Ferreira, R.C.C. ; Ferreira, L.C.S. ; Tran, L.T. ; Schumann, W. (2005). Construction of plasmid-based expression vector for Bacillus subtilis exhibiting full structural stability. Plasmid 54, 241-248.

16. Paccez, J.D.; Luiz, W.B; Sbrogio-Almeida, M.E; Ferreira, R.C.C.; Schumann, W.; Ferreira, L.C.S. (2006). Stable epissomal expression under control of a stress inducible promoter enhances the immunogenicity of Bacillus subtilis as a vector for antigen delivery. Vaccine 24, 2935-43.

17. Paccez, J.D.; Nguyen, H.D.; Luiz, W.B; Ferreira, R.C.C.; SbrogioAlmeida, M.E.; Schumann, W.; Ferreira, L.C.S. (2007). Evaluation of different promoter sequences and antigen sorting signals on the immunogenicity of Bacillus subtilis vaccine vehicles. Vaccine 25, 4671-4680.

18. Paton, J.C.; Paton, A.W. (1998). Pathogenesis and diagnosis of Shiga toxin-producing Escherichia coli infections. Clin. Microbiol. Rev. 11, 450-479.

19. Sambrook, J.; Fritsch, E.; Maniatis, T. (2001). Molecular Cloning: A Laboratory Manual. Cold Spring Harbor Laboratory Press, New York.

20. Smith, M.J.; Teel, L.D.; Carvalho, H.M.; Melton-Celsa, A.R.; O’Brien, A.D. (2006). Development of a hybrid Shiga holotoxoid vaccine to elicit heterologous protection against Shiga toxin types 1 and 2 . Vaccine 24, 4122-4129.

21. Uyen, N.Q.; Hong, H.A.; Cutting, S.M. (2007). Enhanced immunization and expression strategies using bacterial spores as heat-stable vaccine delivery vehicles. Vaccine 25, 356-365.

22. Zhu, C.; Yu, J.; Yang, Z.; Davis, K.; Rios, H.; Wang, B.; Glen, G.; Boedeker, E. C. (2008). Protection against Shiga toxin-producing Escherichia coli infection by transcutaneous immunization with Shiga toxin B subunit. Clin. Vaccine Immunol. 15, 359-366. 